\title{
Re-reading the folie: \\ Louise Labé's Sonnet XVIII and the Renaissance Love Heritage
}

\author{
DEBORAḦ LESKO BAKER
}

\section{$\mathrm{S}$} representation of sexual intimacy. After François Rigolot and Ann Rosalind Jones, Deborah Lesko Baker suggests a new reading of this most famous poem, and attempts to demonstrate how Louise Labé employs and ironizes the Petrarchan poetic tradition. Sonnet XVIII becomes thus a concerted dialogue with Petrarch's Canzoniere.

In the poem-by-poem analyses accompanying his 1972 edition of Louise Labé's sonnets, Peter Sharratt remarks that although sonnet XVIII is probably the most celebrated text of the lyonnais poet's corpus, it is among the most difficult to discuss. ${ }^{1}$ Indeed, with the exception of Sharratt's own commentary and the more recent penetrating analyses by François Rigolot, Peggy Kamuf and Ann Rosalind Jones, critical response to Labé's sonnets often tends to make limited or generalized reference to this anthology favorite. ${ }^{2}$ It is not hard to speculate on why this might be so. Sonnet XVIII is, after all, far from subtle in its immediate and forceful suggestion of sexual intimacy, and although its conclusion waxes philosophical with an overt Neoplatonic turn, it quite frankly does not at first seem all that deep or in need of intensive "explication.

As with much Renaissance poetry, however, some of the most fruitful insights come from a careful investigation of the text in relationship to its anterior and contemporary poetic traditions. For example, after pointing out the multiplicity of traditions that inform Labé's sonnet (the Latin Basium, Neo-latin poetry, Pléiade aesthetics, Biblical humanism, Cabalism, and Neoplatonism), Rigolot concentrates most strongly on the unexplored theological element as he develops the compelling link between the lips (from the Latin labia, evoking the name Labé) that embrace/speak in the poem and the 
Biblical drama of language from Genesis, to Babel, to Pentecost. On the nearer side of the spectrum of influence stand the Renaissance movements of Petarchism and Neoplatonism, and it is here, I believe, that more remains to be said. In her seminal article on the poetics of Louise Labé and Pernette du Guillet, Ann Rosalind Jones stresses that "women poets wrote within but against the center of the traditions that surrounded them, using Neoplatonic and Petrarchan discourse in revisionary and interrogatory ways." ${ }^{3}$ If Labé's revision of Neoplatonism in sonnet XVIII has already been observed, her subversion of the Petrarchan tradition deserves more specific and detailed attention. A new close reading of the poem can sensitize us to the details of poet language that effectuate Louise Labé's challenge to both of these Renaissance traditions. Such a reading can reveal that sonnet XVIII, perhaps more than any other single poem, creates an original and compelling set of values for the female poetic speaker's amatory discourse as well as for her sense of self.

Baise m'encor, rebaise moy et baise:

Donne m'en un de tes plus savoureus,

Donne m'en un de tes plus amoureus:

Je t'en rendray quatre plus chaus que braise.

Las, te pleins-tu? ça que ce mal j'apaise,

En t'en donnant dix autres doucereus.

Ainsi meslans nos baisers tant heureus

Jouissons nous l'un de l'autre à notre aise.

Lors double vie à chacun en suivra.

Chacun en soy et son ami vivra.

Permet m'Amour penser quelque folie:

Tousjours suis mal, vivant discrettement,

Et ne me puis donner contentment,

Si hors de moy ne fay quelque saillie. ${ }^{4}$

Whether we follow Enzo Giudici's bipartite division of the sonnet into a "partie scénique" (11.1-8) and a "partie monologique" (11.9-14) (Guidici, 188 ) or Rigolot's tripartite division including "un appel à la jouissance" (1.1-8), "une leçon philosophique" (1.9-10) and "un aveu personnel" (1.1114) (p.17), what emerges blatantly in the first part of the poem is the famous depiction of erotic intimacy between the poetic speaker and her lover. Of course, this very depiction or sensual communion is in itself the overarching 
subversion of Petrarchan discourse, which is based on the self-turned suffering of a poetic speaker consigned to love an absent, inaccessible Beloved. But beyond the anti-Petrarchan sensuality as a thematic construct, the semantic and rhetorical structure of the quatrains fights against the isolated, autoreflexive character of the Petrarchan speaker. Line one's triple imperative not only replace solitary contemplation by a concrete event in media res (Rigolot, 17), but puts the call for action squarely on the Other rather than on the Self. In addition, the highly chiasmic structure of the second-person imperatives and first-person pronouns in this line is the first rhetorical signal of a reciprocity and mutual exchange between lovers which Petrarchan discourse categorically denies.

This crucial notion of reciprocity and mutual exchange is strengthened by other elements of diction in the two quatrains. Adjective and pronoun structures here are key. Whereas the Petrarchan speaker collapses into the solipsistic $j e$ and prefers the more distant elle to the more proximate $t u$, there is an exactly equal number (six) of first and second-person pronouns or possessive adjectives in lines one through six. Moreover, Labé employs the quintessential verbs of exchange, the couple "donner-rendre" (11. 2-4, 6), as a complement to the verb "baiser" in evoking the shared kisses. ${ }^{5}$ In lines seven and eight, both verbs and pronoun/adjective structures reflect a movement from satisfying reciprocity and exchange to joyous unification. Here the mingling of boundaries between Self and Other captured by the present participle "meslans" culminates in the almost hyperbolic enumeration of first-person plural forms:

Ainsi meslans nos baisers tant heureus

Jouissons nous l'un de l'autre à notre aise.

The nous form as imperative, pronoun, or possessive adjective is rare in male-authored Petrarchan sequences and when used evokes a profoundly different type of union. In Labé's lyonnais contemporary, Maurice Scève, whose volume Délie is the first important French imitation of Petrarch's Canzoniere, this structure occurs only in the final poems of the love sequence, when after a long separation from his Beloved the speaker approaches a partial transcendence of his unsatisfied experience. ${ }^{6}$ Labé's nous brings the possibility of the lovers' union back to earth and makes the achievement of satisfaction a joint effort!

Up to this point we have studied clearly anti-Petrarchan verbal and pronomial structures. But a final view of this sonnet's first part shows that Labé also employs, but deftly ironizes, certain key elements of the Petrarchan 


\section{8 / Renaissance and Reformation}

vocabulary. By ending the first quatrain with the word "braise," she draws attention to the whole scope of Petrarchan fire imagery, which typically evokes either the consuming pain of unrequited desire or the salutary purgation provided by the acceptance of suffering. In Labé's use, of course, the intensity of deprivation is transformed into the intensity of sensual fulfillment, and the term becomes associated with an erotic surfeit rather than a lack (especially since the speaker's kisses are hyperbolically metaphorized as "plus chaus que braise"). Even more striking is the semantic richness of line five, which features a series of conventional terms which might well be used to describe the plight of the unhappy Petrarchan lover: "Las," a diminutive of hélas, thus an exclamation of suffering; "se plaindre," a classic verb of suffering or complaints; and "mal," the nominalization of that suffering. Here Labé's irony becomes quasi-humorous as the poetic speaker seeks to relieve the "pain" of her still un-satiated lover's appetite by accelerating the rate of her kisses. ${ }^{7}$ Certainly no one would pity this lover's plight! And in a final subtle barb to her tradition's crisis of deprivation, Labé ends the line with the verb "apaiser," which in invoking the notion of relief, also invokes the notion of peace (paix, or the Italian pace) so dear yet elusive to the Petrarchan lover. For that traditional Petrarchan lover, peace might only be imagined after death, or at least after an extended period of absence and distance from the Beloved. ${ }^{8}$ In Louise Labé's erotic scene, more contact - not more distance is the answer, and relief or peace is as close in time as it is in space. The only death that could conceivably bring relief in this sonnet would be a symbolic sexual one.

With its abrupt change in tone, the first tercet ushers forth the unexpected philosophical implications of the poem's opening scene:

Lors, double vie à chacun en suivra.

Chacun en soy et son ami vivra. (11.9-10)

Most commentators have pointed out in these lines Labé's formulation of an omnipresent Neoplatonic maxim: that true love involves a transmigration and exchange of souls in which the lovers "die" unto themselves only to be reborn in their spiritual union with the Beloved. In her book Images littéraires de la femme à la Renaissance, Madeleine Lazard emphasizes that whereas fellow lyonnais poets Maurice Scève and Pernette du Guillet can conceive of a metaphysical conjunction of lovers only through the transcending of erotic desire, Louise Labé exults physical love as the catalyst of complete spiritual union. ${ }^{9}$ Her revision of Neoplatonism therefore, is a much more open accommodation of sexual love; more than a catalyst, in fact, sexual love becomes 
the emblem or analogy for Platonic union. But there is a further revision of the tradition as well. In Louise Labé's diction, the accent falls not on the idea of figurative self-death occurring as the lover's soul migrates toward the Beloved's, but on the idea of double life: life within the Beloved and life within the Self. The priority given to a double existence is affirmed as well in the language of the text, since "life" appears both as a substantive and as a verb. In this affirmation of life, there is no denial or subjugation of the self - just continued reciprocity with the Other. ${ }^{10}$

Even in the midst of Labé's revision of a fundamental Neoplatonic principle, her dialogue with the Petrarchan tradition subtly continues. In lines nine and ten she subverts once again the Petrarchan notion of spiritual union as something conceivable only at a great temporal distance from the Beloved. She pointedly ends these two lines with verbs in the future, a tense which her Petrarchan contemporary Scève uses exclusively in the final poems of Délie to envision that far-away moment beyond earthly life when oneness with his Beloved might be possible. In fact, Labé's two verbs, "suivra" and "vivra," are the final two verbs of Scève's entire sequence. But Labé introduces her own future verbs by the sharply anti-Petrarchan adverb "Lors," which defines the lovers' spiritual unification as close at hand, coming right on the heels, as it were, of their passionate embraces. These two future tenses, therefore, have the same temporal status as the "rendray" in line four, which suggests the ease and rapidity with which kisses are exchanged. By ironizing the Petrarchan verbs, Louise Labé posits the doubly un-Petrarchan idea of an undelayed and unproblematic access to spiritual union through the very agency of physical love. ${ }^{11}$

The final line of the first tercet is both pivotal and problematic. Labé's return to the imperative is profoundly different here as she appears to replace the passionate address to her lover with an earnest request for permission from personified Love to contemplate some sort of madness. How can we fruitfully make sense of this line? To my mind, an enlightening reading has been offered by Rigolot, who suggests that the speaker is asking permission from Platonic Love to accept the notion that real love does indeed go beyond the limits of reason, that the very search for union with the Other is a kind of madness. ${ }^{12}$ But if the Neoplatonic exchange of souls is in itself accepted as a concept exceeding human reason, still the kind of "folie" for which Labé is asking permission seems much more extreme and potentially more shocking. I would propose that the madness which the poet wants valorized here is her own departure from the Neoplatonic and Petrarchan traditions that determine her discourse. In this light, the "Amour" being addressed in line eleven might be 
viewed not only as the personification of spiritualized or Platonic love, but also as the love god Cupid who hovers over the Petrarchan love lyric, instilling a passion that is strictly non-reciprocal and forever unattainable. Surely a revision of Neoplatonism which openly designates physical union as an emblem of spiritual union and which stresses continued life in the Self (rather than self-death) in the movement toward life within the Other might seem aberrant or "mad." Likewise, a revision of Petrarchism which replaces the anguished solitary lover with a vision of the couple unified physically and spiritually on earth defies the very rationale of the system and thus also is "mad."

In sum, then, the "folie" of this poem is more than the realm beyond reason to which passion can carry a lover; it is the movement beyond the limits of literary tradition that the artist carries out in her poetic creation. And as the punctuation ending line eleven suggests, the "folie" can be referred not only back to what has already been said, but ahead to the speaker's culminating statement. From this point of view, the second tercet is an elaboration and a refinement of the first. Abandoning the semi-didactic tone and third-person perspective of lines ten and eleven, the poet reassumes her passionate firstperson voice to continue defining the "madness" - that is, her passage beyond the boundaries of her twin contemporary love traditions:

Toujours suis mal, vivant discrettement,

Et ne me puis donner contentement,

Si hors demoy ne fay quelque saillie.

As in the previous tercet, Labé's exploration of the "folie" involves a nuanced ironization of both Neoplatonic and Petrarchan diction and ideas. First, the double sense of the adverb "discrettement" in the sixteenth century (Rigolot, 18; Sharratt, 91; Jones, CE 172) seems simultaneously to connect and to sever the speaker from conventional discourse. In its ontological meaning of separateness, "discrettement" appropriately describes the state of solitude that eternalizes the "mal" of the Petrarchan lover; likewise it captures a grief-provoking failure to achieve the union with the Other on which Neoplatonic love is based. On the other hand, when "discrettement" is taken to mean "wisely" or "properly" in the moral sense, the lasting suffering which the speaker expresses in line twelve ("Toujours suis mal") seems ill-fitted to either tradition. In the typical Neoplatonic dictum, lovers willingly accept to pursue their spiritual union with prudent restraint. And in Petrarchan poetry, although the lover may not overcome the pain of being separate and alone, 
he generally valorizes the moral propriety which will hopefully gain him some distant heavenly reward. ${ }^{13}$

From this curiously divided statements - and the first, moreover, that seems to focus on the speaker's inner emotions - Labé moves to another compelling subversion of conventional rhetoric. Her speaker in line thirteen turns further inward with an overtly self-reflexive utterance addressing how she might give herself satisfaction. ${ }^{14}$ Such self-reflexive language is a major feature of the Petrarchan voice, in which it encapsulizes the lover's fall into self-obsession as a reaction to a feminine presence which is amorphous at best. ${ }^{15}$ However, the traditional solipsistic associations of Labé's reflexive language are sharply overturned in the closing line by a final and even more striking ironization of Petrarchan diction. This line tells us that the condition required by the speaker to gain self-satisfaction is the ability to move "outside of herself" - "hors de moy."16 The expression "hors de moy" in Petrarchan terms, as used by Scève, for example, conveys the tortured lover's perceived breakdown and loss of Self in response to the conflicted contemplation of his unfulfilled love experience. ${ }^{17}$ In taking up this highly charged phrase, Labé dramatically replaces its traditional meaning with her own: going "outside of herself" is nothing other than the quest for a multifaced lover's union that she has pursued throughout the poem. Thus, that self-reflexive rhetoric noted in line thirteen, far from suggesting a wounded Petrarchan self falling into solipcism, demonstrates a strong, integrated self that understands its own happiness depends not on interiority, but on exteriority - on the active pursuit of life with the Beloved. ${ }^{18}$ Additionally, it goes almost without saying that Labé's "hors de moy" simultaneously reinvokes the Neoplatonic vocabulary, while broadening and transforming it through the speaker's insistence on fulfilled desire as a prerequisite to complete union.

We need to turn, finally, to Labé's choice of the curious word "saillie" to conclude her sonnet. Like the word "discrettement" in line twelve, "saillie" enjoys several different connotations within its basic meaning of a forceful rupture or "breaking out" (Rigolot, 19; Sharratt, 91-92; Jones, CE 172). One unavoidable connotation here is sexual, since in the sixteenth century the word is already used to refer to animal copulation. In this sense the speaker clearly plays on her will to abandon moral discretion by implicitly relating the amatory union celebrated in her poem to a consumated sexual act. But it would be too simple to accept that Labé uses such a powerful word only to make a sexual pun. "Saillie" is also a military term in the Renaissance, designating an aggressive outward movement of attack. To my mind, this combattive connotation suggests the conflictual posture that Labé forges 
toward her contemporary Petrarchan and Neoplatonic traditions, and her use of the word strongly reflects the "breaking out" of these traditions that her sonnet achieves. This is all the more plausible in that the sixteenth century also gives the word "saillie" a verbal sense, that being any sort of rhetorical digression, oddity, or excess. ${ }^{19}$ Labé's manipulations of conventional diction and rhetoric throughout the sonnet function expressly as such oddities, as such provocative "saillies," or verbal sallies away from the discourse of her male-authored models. If the erotic "saillie" or consumation will help bring the speaker satisfaction on the personal level, it is the creative "saillie" or revision of tradition that will bring the poet satisfaction on the artistic level.

In conclusion, Louise Labé's famous journey outside of herself ("hors de moy") in sonnet XVIII is at last a courageously double one. Paradoxically, in imagining the love experience as a move outward toward the Other, toward a fully-realized spiritual and physical union in this life, she overcomes the ontological disorientation of the Petrarchan lover and recuperates a positive sense of internal selfhood for the lyric speaker. At the same time, and equally paradoxically, in implicitly defining her artistic endeavor as an outward reach to explore and transform the diction of her poetic Others, she arrives at the creation of an original voice, and comes back to find an authentic poetic self.

\section{Georgetown University}

\section{Notes}

1. Louise Labé. Sonnets, introd. and commentaries by Peter Sharratt (Austin: University of Texas Press, Edinburgh Bilingual Library 7, 1972), 89.

2. François Rigolot. "Signature et signification: Les baisers de Louise Labé, Romanic Review 75:1 (1984) 10-24; Peggy Kamuf. "A Double Life (Femmeninism II)," in Men in Feminism, ed. Alice Jardine and Paul Smith (New York: Methuen, 1987) 93-97; Ann Rosalind Jones. The Currency of Eros: Women's Love Lyric in Europe, 1540-1620 [CE] (Bloomington: Indiana University Press, 1990), 171-172.

3. Ann Rosalind Jones. "Assimilation with a Difference: Renaissance Women Poets and Literary Influence," Yale French Studies 62, (1981) 135.

4. Louise Labé. Oeuvres complètes, ed. Enzo Giudici (Genève: Librairie Droz, 1981). Peggy Kamuf's English translation (Jardine, ed. 271) is useful for its careful attention to the diction of the original:

Kiss me again, and again, and again:

Give me one of your most delicious ones,

Give me one of your most loving ones:

I will give you back four hotter than coals.

Alas, are you suffering? That is the ill I shall soothe

By giving you ten more, sweeter still. 
Thus mingling our happy kisses

Let us enjoy one another at our leisure.

From there will follow a double life for each.

Each will live in self and in the beloved.

Permit (me) my Love to think a certain madness:

I ma always unwell, living discreetly,

And can give myself no contentment,

If I do not go outside myself.

5. In commenting on Labé's revision of Catullus' famous lines calling his mistress to join him in a hyperbolic exchange of kisses, Jones stresses the female poet's appropriation of the traditionally male kiss poem and suggests that Labé's "direct command and her promise to reciprocate, even to outdo her male lover, typify her posture as amorous and poetic rival" (CE 171).

6. For examples of Scève's use of the nous form as well as Labé's reworking of it in her Sonnet 13, see my "Louise Labé's Conditional Imperatives," Sixteenth Century Journal 21:4 (1990) 528-529.

7. In "Louise Labé's Deceptive Petrarchism," Modern Language Studies 9 (1981), 52, Karen F. Wiley points out the "crooning, motherly accents" of this line, which she sees blending with and enhancing the sensuality of the poem. Jones observes a similar dual positioning of the female speaker as "maternal-sounding soother of pain" and "inviter to shared pleasure" (CE 171).

8. Petrarch's lyric speaker declares in the penultimate poem of the Canzoniere:

si che, s'io vissi in guerra et in tempesta

mora in pace et in porto: et se la stanza

fu vana, almen sia la partiat onesta (S. 365, 11.9-11)

Quotations of the Canzoniere are from Petrarch's Lyric Poems, ed. and trans. Robert Durling (Cambridge: Harvard University Press, 1976).

9. Madeleine Lazard. Images littéraires de la femme à la Renaissance (Paris: Presses Universitaires de France, 1985) 52.

10. See Kamuf (94-95) for a suggestive discussion of Louise Labé's original twist on this Neoplatonic motif.

11. For a more ambivalent view of the effect of Labé's future tenses in 11.9-10, see Rigolot (18).

12. Rigolot (18). Rigolot's argument here is substantiated with convincing references to Labé's Débat de Folie et d'Amour, in which the relationship between these two notions is explored in an allegorical trial directed by the Olympian gods. Jones sheds additional light on the various levels of apology at stake in this plea to Love, in the context of Labé's position as poet and woman in sixteenth-century France (CE 172).

13. Kamuf (95) goes so far as to read Labé's "suis mal" as an assertion of "unbeing" rather than of suffering, a profound ontological lack provoked by the double-edged notion of "vivant discrettement." 


\section{4 / Renaissance and Reformation}

14. Rigolot's close reading notes: "Au vers 13 ('Et ne me puis donner contentment') l'infinitif réfléchi indique que l'amante est à la fois sujet et objet de son plaisir ambigu: elle se donne à elle-même la satisfaction d'échapper à la raison" (19).

15. See, for example, the Petrarchan speaker's self-reflexive shame in Sonnet I of the Canzoniere: "di ne medesmo meco mi vergogno," 1. 11. In the Délie, Scève's lyric speaker utters similar self-referential structures, as in D. 317, 1. 1: "Mon mal se paist de mon propre dommage." Scève quotations are from The Délie of Maurice Scève, ed. I.D. McFarlane (Cambridge: Cambridge University Press, 1966).

16. Note that Labé's avoidance of the je in this line subtly underlines the movement outside the self.

17. See D. $93,1.7-10$ :

Car moy constraint, \& par forcée preuue

Le soir me couche esueillé hors de moy,

Et le matin veillant aussi me treuue,

Tout esploré en mon piteux esmoy.

18. For the notions of interiority and exteriority applied to the lyric speaker, see Peter Baker. Obdurate Brilliance: Exteriority and the Modern Long Poem (Gainesville: University of Florida Press, 1991). Although as the title indicates, Baker's work treats long poems in the modernist and postmodernist movements, his theoretical distinctions are useful for the study of the Renaissance lyric tradition.

19. Sharratt (91-92) notes Cotgrave's example of "saillie" used in a verbal sense, and cites a particularly apt quotation from Montaigne - one which beautifully highlights the "artistic" dimension of Labé's conclusion:

"Les saillies poétiques, qui emportent leur auteur et le ravissent hors de soy, pourquoy ne les attribuerons nous à son bonheur?" (I, XXIV) 